\title{
Vacuolar ion channels in the liverwort Marchantia polymorpha: influence of ion channel inhibitors
}

\author{
Mateusz Koselski $^{1}{ }_{(\mathbb{D}} \cdot$ Kazimierz $_{\text {Trebacz }}{ }^{1} \cdot$ Halina Dziubinska $^{1}$
}

Received: 17 November 2016/Accepted: 7 February 2017/Published online: 14 February 2017

(c) The Author(s) 2017. This article is published with open access at Springerlink.com

\begin{abstract}
Main conclusion Potassium-permeable slow activating vacuolar channels (SV) and chloride-permeable channels in the vacuole of the liverwort Marchantia polymorpha were characterized in respect to calcium dependence, selectivity, and pharmacology.
\end{abstract}

The patch-clamp method was used in the study of ion channel activity in the vacuoles from the liverwort Marchantia polymorpha. The whole-vacuole recordings allowed simultaneous observation of two types of currents-predominant slow activated currents recorded at positive voltages and fast activated currents recorded at negative voltages. Single-channel recordings carried out in the gradient of $\mathrm{KCl}$ indicated that slow activated currents were carried by potassium-permeable slowly activating vacuolar channels (SV) and fast activated currents-by chloride-permeable channels. Both types of the channels were dependent in an opposite way on calcium, since elimination of this ion from the cytoplasmic side caused inhibition of SV channels, but the open probability of chloride-permeable channels even increased. The dependence of the activity of both channels on different types of ion channel inhibitors was studied. SV channels exhibited different sensitivity to potassium channel inhibitors. These channels were insensitive to $3 \mathrm{mM} \mathrm{Ba}^{2+}$, but were blocked by $3 \mathrm{mM}$ tetraethyl ammonium (TEA). Moreover, the activity of the channels was modified in a different way by calcium channel inhibitors. $200 \mu \mathrm{M} \mathrm{Gd}^{3+}$ was an effective

Mateusz Koselski

mateusz.koselski@poczta.umcs.lublin.pl

1 Department of Biophysics, Institute of Biology and Biochemistry, Maria Curie-Skłodowska University, Akademicka 19, 20-033 Lublin, Poland blocker, but $50 \mu \mathrm{M}$ ruthenium red evoked bursts of the channel activity resulting in an increase in the open probability. Different effectiveness of anion channel inhibitors was observed in chloride-permeable channels. After the application of $100 \mu \mathrm{M} \mathrm{Zn}{ }^{2+}$, a decrease in the open probability was recorded but the channels were still active. $50 \mu \mathrm{M}$ DIDS was more effective, as it completely blocked the channels.

Keywords Calcium dependence - Chloride channels . Patch-clamp · Pharmacology - SV channels · Vacuole
Abbreviations
ALMT
$\left[\mathrm{Ca}^{2+}\right]_{\mathrm{cyt} / \mathrm{vac}}$
Aluminium-activated malate transporter
$\mathrm{E}_{\mathrm{K} / \mathrm{Cl}}$
SV
TEA
Concentration of calcium in the cytoplasm/vacuole
TPC1
Reversal potential for potassium/chloride
Slowly activating vacuolar channel
Tetraethyl ammonium
Two-pore channel 1

\section{Introduction}

Bryophytes were among the first plants that colonized lands. These pioneer plants had to be evolutionally equipped to cope with turbulences in accessibility of water and nutrients. Central vacuoles playing a role of an alternative water environment and possessing appropriate ion channels seem to fulfil an important role in the process of adaptation to the land conditions. The ubiquitous liverwort Marchantia polymorpha was the object of our study. This plant was selected by geneticists as a model liverwort and its genome is continuously published. This will soon open the possibility of combining in silico analysis with ion 
channel behaviour. The only other liverwort whose ion channels in the vacuole have been studied is Conocephalum conicum closely related to $M$. polymorpha. In Conocephalum, like in most plants tested so far, the Slowly activating Vacuolar channel SV is the most abundant ion channel (Trębacz and Schönknecht 2000; Trębacz et al. 2007). SV channels in C. conicum exhibit typical slow kinetics of activation. They are permeable to both monoand divalent cations. SV channels strongly rectify, allowing cation transport from the cytosol to the vacuolar lumen but not in an opposite direction. What distinguishes SV channels in $C$. conicum from these in vascular plants, is the higher threshold of the cytoplasmic $\mathrm{Ca}^{2+}$ concentration $\left[\mathrm{Ca}^{2+}\right]_{\text {cyt }}$ necessary for their activation (over $100 \mu \mathrm{M}$ ) and the relatively low impact of luminal calcium $\left[\mathrm{Ca}^{2+}\right]_{\mathrm{v}}$ on their open probability (Trębacz et al. 2007). In vascular plants, SV channels are regulated by a plethora of factors including $\mathrm{Mg}^{2+}, \mathrm{Zn}^{2+}, \mathrm{pH}$, polyamines, terpenes, choline, dithiothreitol, glutathione, and heavy metals (reviewed by Pottosin and Schönknecht 2007; Hedrich and Marten 2011). A pharmacological approach revealed susceptibility of SV currents to different inhibitors of cation channels from animal cells including tetraethyl ammonium (TEA), amino-acridine, (+)-tubocurarine, quinacrine, and quinidine (Weiser and Bentrup 1993). SV currents were also blocked by ruthenium red, an inhibitor of $\mathrm{Ca}^{2+}$ release channels in animal endomembranes (Pottosin et al. 1999). Modulation of the channels, i.e. long-lasting changes in their activity, is induced by phosphorylation/dephosphorylation (Allen et al. 1995; Bethke and Jones 1997), calmodulin (Bethke and Jones 1994), and 14-3-3 proteins (van den Wijngaard et al. 2001).

The discovery that the two-pore channel 1 (TPC1) gene encodes the SV channel protein in Arabidopsis thaliana (Peiter et al. 2005) was a milestone that opened examination of the SV/TPC1 channel structure and structure/function relations. Recently, a crystal structure of the channel from A. thaliana was published (Guo et al. 2016). The features of SV/TPC1 channels established by electrophysiological experiments are reflected in the structure of the protein (Schulze et al. 2011; Jaslan et al. 2016).

Despite the massive progress in deciphering the structure of the SV/TPC1 channel, its physiological role is still a matter of debate. It is postulated that the channel plays a role of a "safety valve", which in steady state conditions remains closed. A number of "security" systems in the SV/ TPC1 channel serve its opening only in drastic conditions, such as those evoking action potentials (AP). APs in a liverwort closely related to $M$. polymorpha, i.e. C. conicum, are generated in response to different kinds of stimuli, including light (Trebacz and Zawadzki 1985), electrical stimulation (Dziubinska et al. 1983), cold (Krol et al. 2003), and menthol (Kupisz et al. 2015). Recently, the role of SV/TPC1 channels in long-distance signalling has been demonstrated (Choi et al. 2014; Kiep et al. 2015). Knockout mutants bearing no functional SV/TPC1 channels were unable to generate $\mathrm{Ca}^{2+}$ waves, which usually accompany spreading electrical signals evoked by wounding or herbivorous larvae (Choi et al. 2014; Kiep et al. 2015).

Anion-permeable channels in plant vacuoles are examined much more seldom than cation channels. Most of the data refer to vascular plants. In higher plants, three different types of transporters catalysing anion flux through the vacuolar membrane have been distinguished at the molecular level: aluminium-activated malate transporters (ALMT) (Pantoja and Smith 2002; Hafke et al. 2003; Kovermann et al. 2007), tonoplast dicarboxylate transporters (tDT) - orthologs of animal $\mathrm{Na}^{+} /$dicarboxylate exchangers (Emmerlich et al. 2003; Hurth et al. 2005), and chloride channels/exchangers (CLC) (Lv et al. 2009; Isayenkov et al. 2010; von der Fecht-Bartenbach et al. 2010).

Anion-permeable channels in Bryophytes characterized so far have been found in the liverwort C. conicum (Trębacz et al. 2007) and the moss Physcomitrella patens (Koselski et al. 2015). The channels in C. conicum are nearly equally permeable to $\mathrm{Cl}^{-}$and $\mathrm{NO}_{3}{ }^{-}$and much less selective to malate. They are activated by an excess of $\mathrm{Mg}^{2+}$ at a low concentration of cytoplasmic calcium $\left[\mathrm{Ca}^{2+}\right]_{\text {cyt }}$ (Trębacz et al. 2007). It was postulated that $\mathrm{Mg}^{2+}$ replaces $\mathrm{Ca}^{2+}$ in a putative regulation place. The anionpermeable channels in $P$. patens exhibit high $\mathrm{NO}_{3}{ }^{-}$ selectivity since the permeability ratio of $\mathrm{NO}_{3}^{-}$to $\mathrm{Cl}^{-}$ $\left(\mathrm{P}_{\mathrm{NO} 3} / \mathrm{P}_{\mathrm{Cl}}\right)$ amounted to 3.08 . The current flux is directed from the cytosol to the vacuole. The current density decreases at $\mathrm{pH}$ below 7.0 . The channels require $\left[\mathrm{Ca}^{2+}\right]_{\mathrm{cyt}}$ higher than $10 \mu \mathrm{M}$ and $\left[\mathrm{Mg}^{2+}\right]_{\text {cyt }}$ above $2 \mathrm{mM}$ for activation (Koselski et al. 2015). In silico research indicated homology between CLC-type proteins in Arabidopsis and in Physcomitrella (Koselski et al. 2015).

This is the first study concerning biophysical characterization of ion channels in Marchantia vacuoles with the application of the patch-clamp technique. Special emphasis was paid to $\mathrm{SV}$ and anion channels.

\section{Materials and methods}

\section{Plant material}

Thalli of $M$. polymorpha were collected in the Botanical Garden of Maria Curie-Skłodowska University in Lublin. Gemmae were taken from the gemma-cups of male plants and placed on peat pellets for cultivation. The plants were cultivated in a vegetative chamber at $23{ }^{\circ} \mathrm{C}$, humidity 
50-70\%, and under a 16:8 h (light:dark) photoperiod with the light intensity of $20-40 \mu \mathrm{mol} \mathrm{m} \mathrm{m}^{-2} \mathrm{~s}^{-1}$. Four to fiveweek-old plants were used for electrophysiological experiments.

\section{Vacuole isolation}

The vacuoles were isolated with the non-enzymatic method described by Trębacz and Schönknecht (2000). Before the experiments, a fragment of a thallus cut from a rhizoid-free area was plasmolysed in a bath medium supplemented with $500 \mathrm{mM}$ sorbitol. After $20-30 \mathrm{~min}$, a fragment of the thallus was cut with a razor blade and transferred to a measuring chamber containing a solution with an osmotic pressure of $500 \mathrm{~m} \mathrm{Osm} \mathrm{kg}^{-1}$ (the value of this parameter in the micropipette was $550 \mathrm{~m} \mathrm{Osm} \mathrm{kg}^{-1}$ ). In such an osmotic pressure, the deplasmolysis of the cells caused release of the protoplast from the cut-off cell walls. After a few minutes, some of the protoplasts ruptured and release of vacuoles was observed.

\section{Patch-clamp experiments}

The patch-clamp experiments were performed in the whole-vacuole and cytoplasm-out configuration. The micropipettes were made from borosilicate tubes (Kwik-Fil TW150-4; WPI, Sarasota, FL, USA), which were pulled and fire polished by a DMZ-Universal Puller (Zeitz-Instruments, Martinsried, Germany). An $\mathrm{Ag} / \mathrm{AgCl}$ reference electrode filled with $100 \mathrm{mM} \mathrm{KCl}$ was connected with the bath solution by a ceramic porous bridge. A cryoscopic osmometer (Osmomat 030; Gonotec, Berlin, Germany) was used for checking the solution osmolarity. The experiments were performed using an EPC-10 amplifier (Heka Electronik, Lambrecht, Germany) working under the Patchmaster software (Heka Electronik). The recordings were sampled at $10 \mathrm{kHz}$ and filtered with $1 \mathrm{kHz}$. The solution in the measuring chamber was exchanged before recording by a peristaltic pump (ISM796B; Ismatec, Wertheim, Germany). The results were presented according to the convention proposed by Bertl et al. (1992).

\section{Analysis of the results}

Current density/voltage (J/V) and current/voltage (I/V) characteristics were prepared in SigmaPlot 9.0 (Systat Software Inc.). The amplitude histograms were fitted in GRAMS/AI 8.0 (Spectroscopy Software). The open probability of the channels was calculated from the area under the Gaussian peaks. The reversal potentials $\left(E_{\text {rev }}\right)$ were calculated based on the activities of the ions used. Due to the non-linear $I / V$ characteristics, the unitary conductance was calculated as a $I / V$ ratio obtained at the specific voltage. The number of repeats $(n)$ indicates the number of tested tonoplast patches or whole vacuoles.

\section{Results}

The whole vacuole measurements carried out in symmetrical (in the bath and in the pipette) $100 \mathrm{mM} \mathrm{KCl}$ allowed observation of slowly activated positive currents and fast activated negative currents (Fig. 1a). Slow kinetics of activation was observed especially at voltages higher than $40 \mathrm{mV}$; it consisted in an increase in the current density recorded during several hundreds of milliseconds after application of the voltage pulse. The density of the fully activated positive currents measured from the marginal part of the recordings (80-95\%) obtained at $100 \mathrm{mV}$ amounted to $0.44 \pm 0.12 \mathrm{~A} / \mathrm{m}^{2}(n=6)$ and was considerably higher than the negative currents recorded at $-100 \mathrm{mV}$ $\left(0.03 \pm 0.01 \mathrm{~A} / \mathrm{m}^{2}, n=6\right)$. Higher densities of both currents were recorded when the concentration of $\mathrm{KCl}$ in the pipette was reduced to $10 \mathrm{mM}$ (Fig. 1c). Application of the $\mathrm{KCl}$ gradient did not cause a shift of the reversal potential measured at the steady state currents, which remained close to zero. A similar value of the reversal potential was also obtained from the tail-current analysis (Fig. 1b). The lack of the reversal potential shift recorded in the $\mathrm{KCl}$ gradient indicated simultaneous activity of two types of ion channels with different selectivity for $\mathrm{K}^{+}$and $\mathrm{Cl}^{-}$in the tonoplast of Marchantia. If both $\mathrm{K}^{+}$and $\mathrm{Cl}^{-}$ions flowed through the tonoplast in the same direction, the wholevacuole outward currents could be balanced by inward currents. To examine such a possibility, we carried out measurements in the cytoplasm-out configuration, which allowed us to record the activity of single ion channels (Fig. 2). The cytoplasm-out measurements showed that channels recorded at positive and negative voltages had different conductance, which at $100 \mathrm{mV}$ amounted to $18 \pm 1 \mathrm{pS}(n=8)$ and at $-100 \mathrm{mV}$ to $49 \pm 1 \mathrm{pS}$ $(n=11)$. Moreover, at negative voltages, usually one channel was active whilst the number of active channels at positive voltages increased together with the magnitude of the applied voltage (Fig. 2a). The amplitudes of recorded currents allowed drawing two $I / V$ curves, separately for positive and negative currents, which crossed the abscissa at different voltages indicating simultaneous activity of two types of channels with different selectivity (Fig. 2d). The values of the reversal potential estimated from the I/ $V$ curves amounting -56 and $38 \mathrm{mV}$ were close to the reversal potentials for potassium $\left(E_{\mathrm{K}}=-55 \mathrm{mV}\right)$ and chloride $\left(E_{\mathrm{Cl}}=55 \mathrm{mV}\right)$, respectively. Such results indicated that, at positive voltages, the activity of outwardly rectifying $\mathrm{K}^{+}$-permeable channels was recorded; in turn, at negative voltages, $\mathrm{Cl}^{-}$-permeable channels were active. 

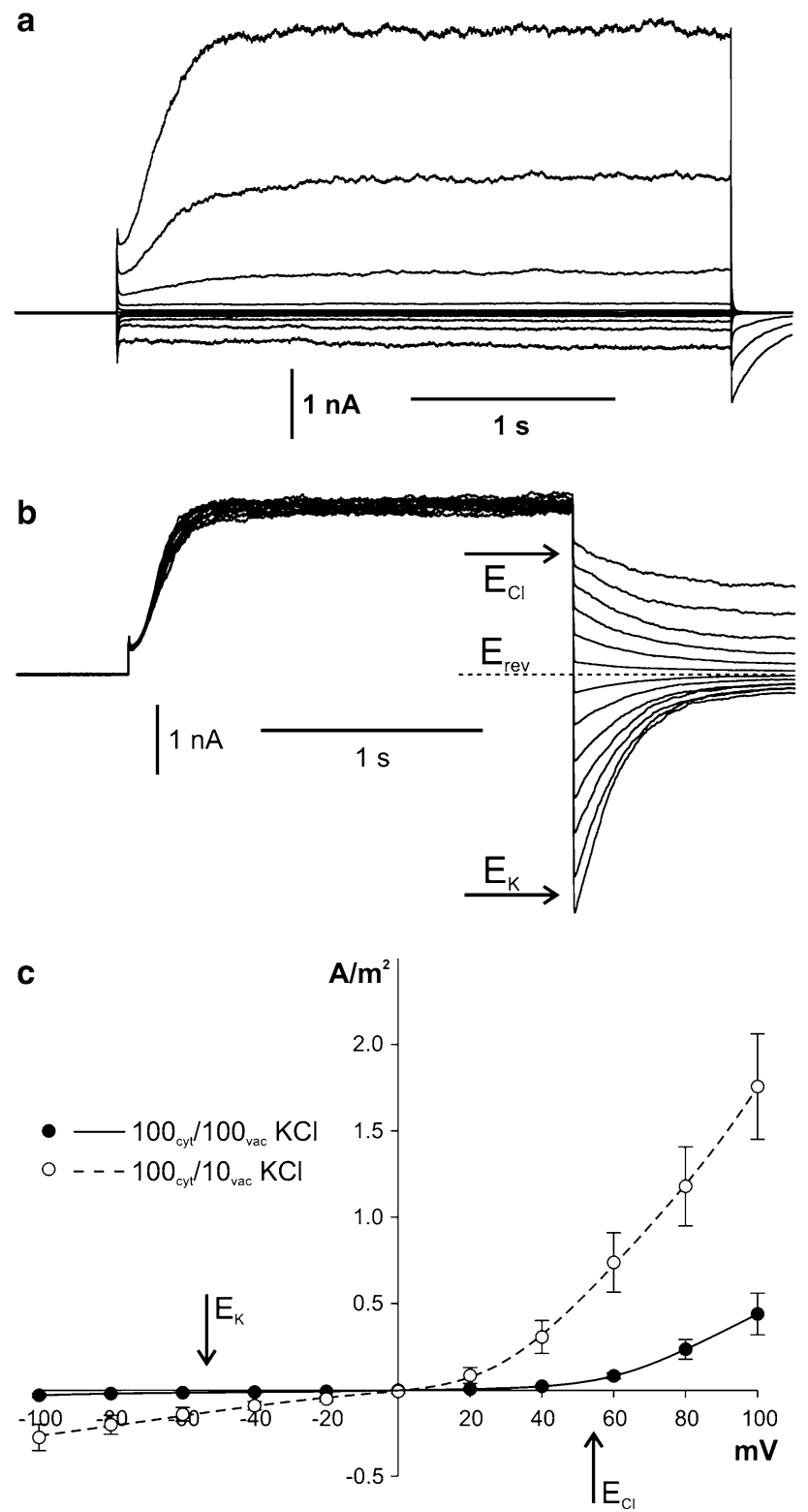

Fig. 1 Activity of ion channels recorded in the whole-vacuole configuration. a Recordings obtained in the symmetrical concentration of $100 \mathrm{mM} \mathrm{KCl}$ (the pipette contained $100 \mathrm{mM} \mathrm{KCl}, 0.1 \mathrm{mM}$ $\mathrm{CaCl}_{2}, 2 \mathrm{mM} \mathrm{MgCl} 2, \mathrm{pH} 5.5$ buffered by Hepes/TRIS, and the bath$100 \mathrm{mM} \mathrm{KCl}, 0.1 \mathrm{mM} \mathrm{CaCl}_{2}, 2 \mathrm{mM} \mathrm{MgCl}_{2}, \mathrm{pH} 7.2$ buffered by Mes/ TRIS). Recordings were obtained by application of $0.5 \mathrm{~s}$ holding voltage $(0 \mathrm{mV})$, then $3 \mathrm{~s}$ test voltages with $20 \mathrm{mV}$ steps from 100 to $-100 \mathrm{mV}$, and $0.3 \mathrm{~s}$ pulse $(0 \mathrm{mV})$ after the test voltage. b Tail currents recorded in the gradient of $\mathrm{KCl}$ obtained after reduction of $\mathrm{KCl}$ in the pipette to $10 \mathrm{mM}$ (the pipette contained $10 \mathrm{mM} \mathrm{KCl}$, $0.1 \mathrm{mM} \mathrm{CaCl}_{2}, 2 \mathrm{mM} \mathrm{MgCl}$, pH 5.5 buffered by Hepes/TRIS). Recordings were obtained by application of $0.5 \mathrm{~s}$ holding voltage $(0 \mathrm{mV})$, then $2 \mathrm{~s}$ voltage which activated $\mathrm{SV}$ channels $(80 \mathrm{mV})$, and $1 \mathrm{~s}$ test voltages with $10 \mathrm{mV}$ steps from -60 to $60 \mathrm{mV}$. The reversal potential (dashed line) and the equilibrium potential for $\mathrm{K}^{+}$and $\mathrm{Cl}^{-}$ (arrows) are indicated. c $J / V$ curves obtained in the symmetrical concentration of $100 \mathrm{mM} \mathrm{KCl}$ (the same conditions as in a, closed circles and solid line, $n=6$ ) and after reduction of the $\mathrm{KCl}$ concentration in the pipette to $10 \mathrm{mM}$ (the same conditions as in $\mathbf{b}$, open circles and dashed lines, $n=7$ )

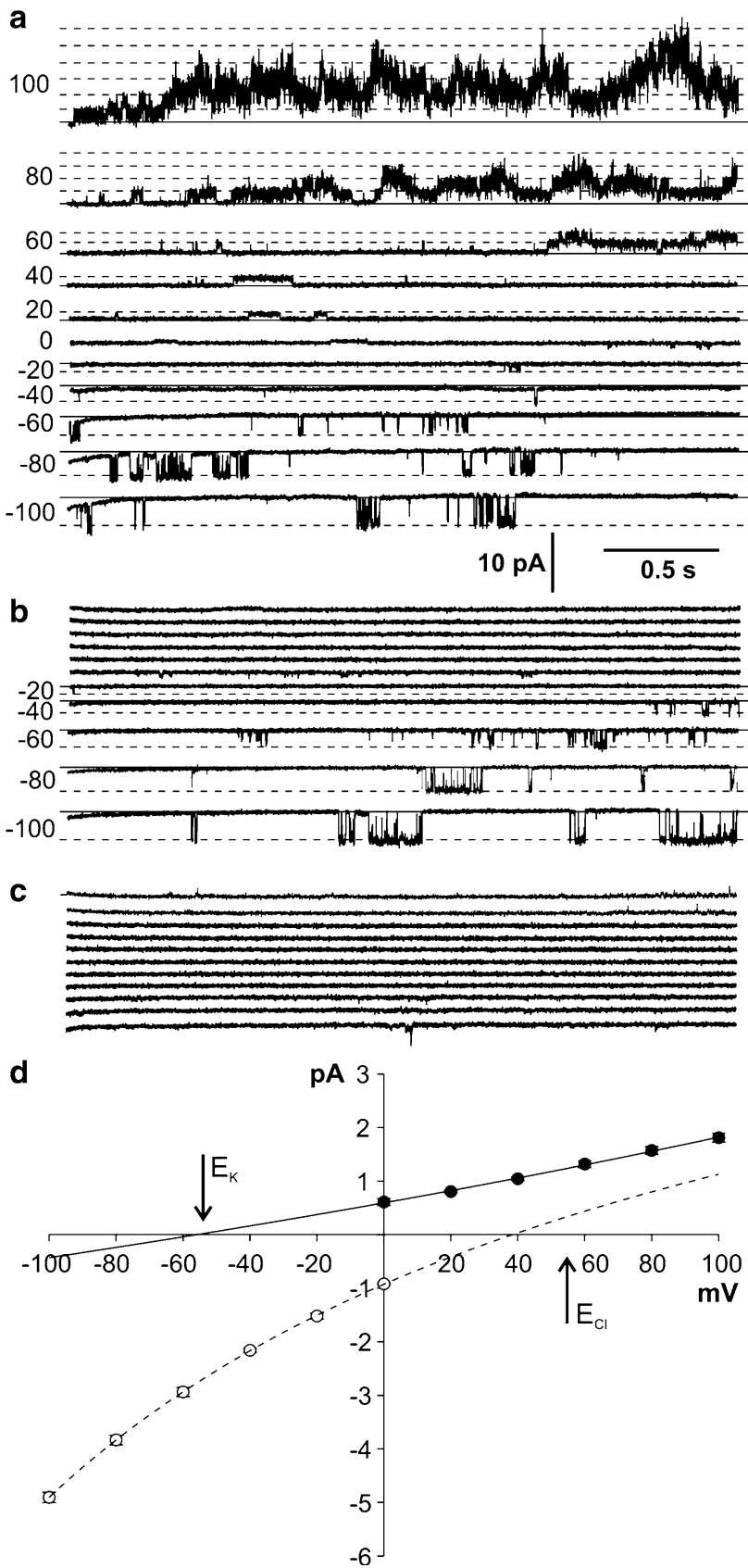

Fig. 2 Activity of ion channels recorded in the cytoplasm-out configuration. a Recordings obtained in the gradient of $\mathrm{KCl}$ (the pipette contained $10 \mathrm{mM} \mathrm{KCl}, 0.1 \mathrm{mM} \mathrm{CaCl}_{2}, 2 \mathrm{mM} \mathrm{MgCl}_{2}, \mathrm{pH} 5.5$ buffered by Hepes/TRIS, and the bath-100 mM KCl, $0.1 \mathrm{mM} \mathrm{CaCl}_{2}, 2 \mathrm{mM}$ $\mathrm{MgCl}_{2}, \mathrm{pH} 7.2$ buffered by Mes/TRIS). Solid lines indicate the close state, and dashed lines-open states of the channels. The holding voltages are placed on the left side of the traces. $\mathbf{b}$ Recordings obtained at the same patch after replacement of $100 \mathrm{mM} \mathrm{KCl}$ in the bath by $100 \mathrm{mM} \mathrm{HCl}\left(100 \mathrm{mM} \mathrm{HCl}, 0.1 \mathrm{mM} \mathrm{CaCl}_{2}, 2 \mathrm{mM} \mathrm{MgCl}_{2}, \mathrm{pH} 7.2\right.$ buffered by BIS-TRIS Propane). $\mathbf{c}$ Recordings obtained after replacement of $100 \mathrm{mM} \mathrm{HCl}$ in the bath by $100 \mathrm{mM} \mathrm{K}$-gluconate $(100 \mathrm{mM}$ K-gluconate, $0.1 \mathrm{mM} \mathrm{CaCl}_{2}, 2 \mathrm{mM} \mathrm{MgCl} 2, \mathrm{pH} 5.5$ buffered by Hepes/ TRIS. d $I / V$ curves obtained in the same conditions as in a. Close circles and the solid line denote currents flowing through SV channels $(n=10)$, and open circles and the dashed line denote currents flowing through chloride channels $(n=11)$ 

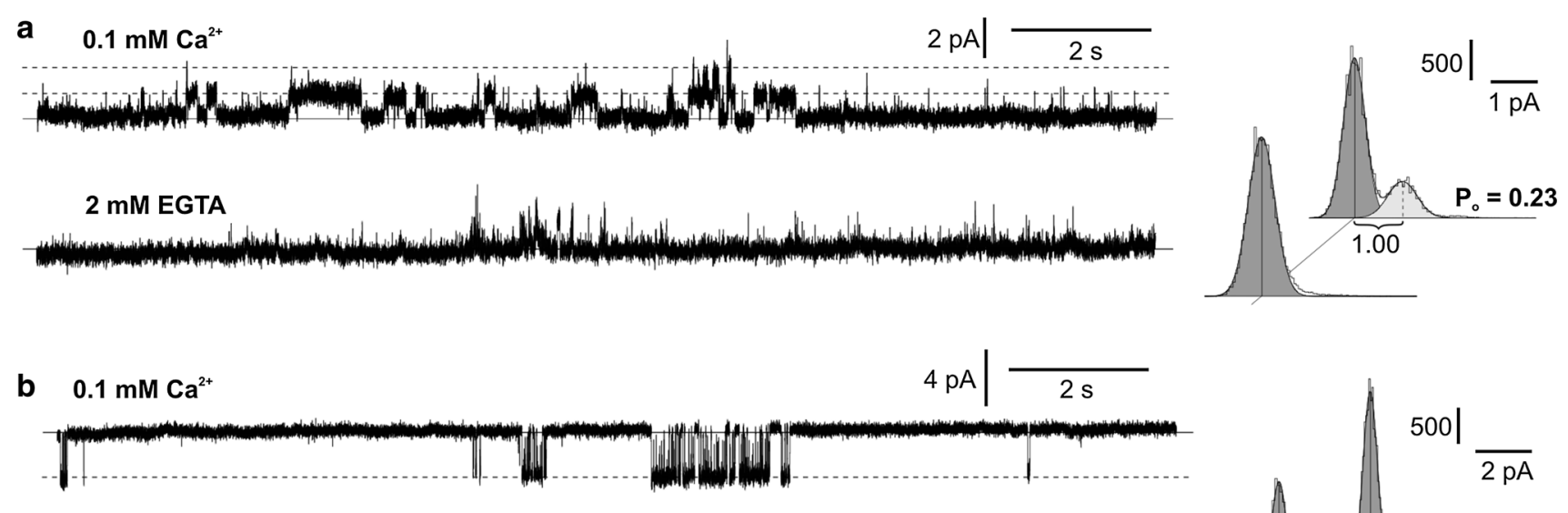

2 MM EGTA
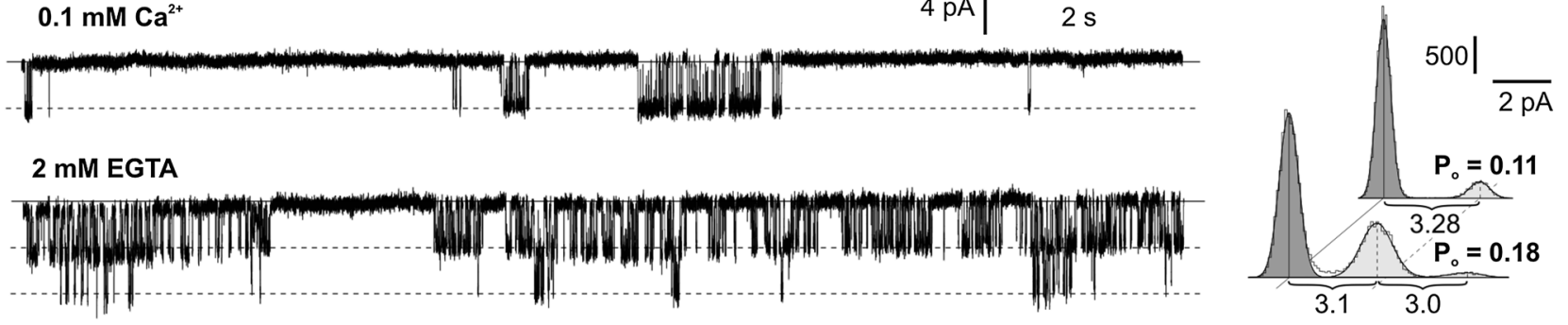

Fig. 3 Calcium dependence of SV channels (a) and chloridepermeable channels (b). The cytoplasm-out recordings were obtained at the same patch at $+40 \mathrm{mV}$ (a) and $-60 \mathrm{mV}$ (b). The traces described as $0.1 \mathrm{Ca}^{2+}$ were obtained in the same conditions as in Fig. 2a. The amplitude histograms indicating the current amplitude (horizontal line) and the number of sample points (vertical line)

The potassium and chloride selectivity of the channels was confirmed in experiments that imposed reduction of $\mathrm{K}^{+}$ and $\mathrm{Cl}^{-}$fluxes from the bath (cytoplasmic side) to the pipette (vacuolar side) by replacement of $\mathrm{K}^{+}$or $\mathrm{Cl}^{-}$in the bath by ions impermeable to potassium or chloride channels, respectively. Elimination of potassium currents was achieved by replacement of $100 \mathrm{mM} \mathrm{KCl}$ by $100 \mathrm{mM} \mathrm{HCl}$ (Fig. 2b). The inactivation of positive currents recorded in the absence of $\mathrm{K}^{+}$in the bath did not inhibit the negative currents, whereas the currents were completely blocked after the replacement of $100 \mathrm{HCl}$ by $100 \mathrm{mM} \mathrm{K}$-gluconate (Fig. 2c).

Many types of vacuolar ion channels are calcium dependent. A majority of vacuolar channels are active in the presence of cytoplasmic calcium and such dependence occurs in SV channels (Allen and Sanders 1996; Pottosin and Schönknecht 2007; Trębacz et al. 2007; Hedrich and Marten 2011; Koselski et al. 2013;), potassium-selective vacuolar channels (VK) (Ward and Schroeder 1994; Allen and Sanders 1996; Allen et al. 1998; Pottosin et al. 2003), fast activated vacuolar channels (FV) (Tikhonova et al. 1997; Allen et al. 1998), one of ALMTs from A. thaliana (AtALMT6) (Meyer et al. 2011), chloride channels from Vicia faba activated by calcium-dependent protein kinase (CDPK) (Pei et al. 1996), and nitrate-permeable channels from $P$. patens (Koselski et al. 2015). The calcium dependence of the ion channels from Marchantia was studied by elimination of $0.1 \mathrm{mM} \mathrm{Ca}^{2+}$ from the cytoplasmic side (Fig. 3). The measurements were carried in a correspond to the traces obtained in standard conditions (upper histogram) and after elimination of cytoplasmic calcium by application of $2 \mathrm{mM}$ EGTA (lower histogram). The diagonal dashed lines indicate open states and the solid line-close states of the channels. The values of the current amplitude and the open probability (Po) were indicated

cytoplasm-out configuration by application of a long lasting (16 s) voltage pulse, which was close to the reversal potentials obtained previously. The selected values of voltage pulses, +40 and $-60 \mathrm{mV}$, guaranteed avoidance of the activity of chloride and potassium channels, respectively. The results obtained in the absence of cytoplasmic calcium indicated different calcium dependence of potassium- and chloride-permeable channels. The inhibition of potassium-permeable channels recorded in the absence of cytoplasmic calcium (Fig. 3a) allowed us to classify the channels to SV channels, the most popular slow activated and calcium-dependent vacuolar cation-permeable channels. An opposite effect was recorded in the case of fast activated chloride-permeable channels, since elimination of cytoplasmic calcium not only did not inhibit the channels but also evoked an increase in the open probability (Fig. 3b). Such results are further evidence for existence of two different channels in the vacuoles of Marchantia, i.e. SV channels and chloride-permeable channels.

Ion channels from Marchantia were characterized in more detail by using ion channel inhibitors. Different effectiveness in blockage of SV channels was obtained after the application of two inhibitors, $\mathrm{BaCl}_{2}(3 \mathrm{mM})$ and TEA (3 mM) (Fig. 4). $\mathrm{BaCl}_{2}$ almost unchanged the activity of the SV channels. According to the amplitude histogram, application of $\mathrm{BaCl}_{2}$ caused slight changes in the open probability (an increase from 0.21 to 0.25 ) and conductance (a decrease from 1.04 to $1.00 \mathrm{pA}$ ) (Fig. 4a). In turn, total blockage of $\mathrm{SV}$ channels was obtained after 


\section{a standard

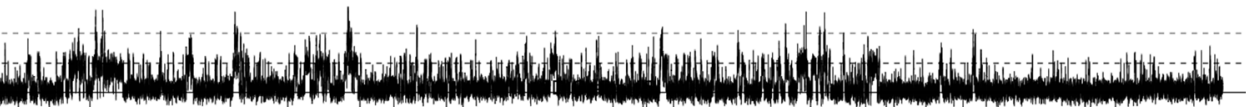

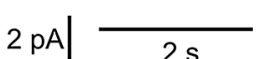
$3 \mathrm{mM} \mathrm{Ba} \mathrm{a}^{2+}$
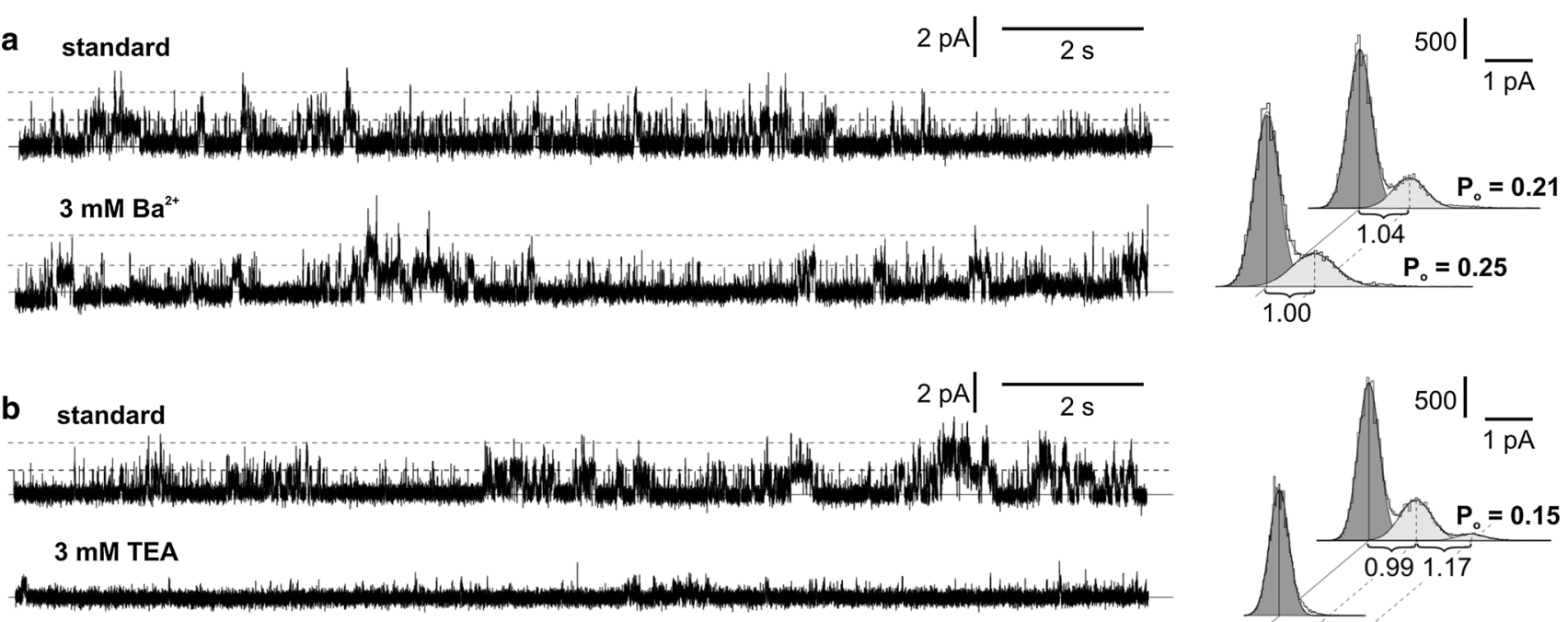

Fig. 4 Influence of potassium channel inhibitors, $\mathrm{BaCl}_{2}$ (a) and TEA (b) on the activity of SV channels. The standard conditions were the same as in Fig. 2a. The cytoplasm-out recordings were obtained at the

application of TEA (Fig. 4b). Different effectiveness of two anion channel inhibitors, $\mathrm{ZnCl}_{2}(100 \mu \mathrm{M})$ and $4,4^{\prime}$ diisothiocyanatostilbene-2,2'-disulfonic acid (DIDS; $50 \mu \mathrm{M}$ ), was recorded in respect to the chloride channel activity (Fig. 5). Application of $\mathrm{ZnCl}_{2}$ did not block the channels but lowered their open probability from 0.10 to 0.02 (Fig. 5a). The effects were observed a few minutes after application of $\mathrm{ZnCl}_{2}$. DIDS was more effective and evoked total blockage of the channels immediately after application (Fig. 5b).

Since SV channels are known to be permeable to monoand divalent cations including calcium, it was interesting to examine if SV channels from Marchantia share common same patch at $+40 \mathrm{mV}$. The amplitude histograms correspond to the traces obtained in standard conditions (upper histogram) and after application of the inhibitor to the bath solution (lower histogram)

features with calcium channels and are sensitive to calcium channel inhibitors. We decided to study the sensibility of the channels on two calcium channel inhibitors: $\mathrm{GdCl}_{3}$ $(200 \mu \mathrm{M})$ and ruthenium red $(50 \mu \mathrm{M})$. Complete blockage of SV channels was recorded after application of $200 \mu \mathrm{M}$ $\mathrm{GdCl}_{3}$ (Fig. 6a). In comparison to gadolinium, ruthenium red evoked almost opposite effects to the activity of the SV channels (Fig. 6b). In a majority of the tested patches (5 of 7), this inhibitor evoked bursts of rapid flickering of SV channels between open and close states. This phenomenon was accompanied by an increase in the open probability from 0.29 to 0.43 . The event detection analysis indicated that ruthenium red evoked an increase in the short-lasting

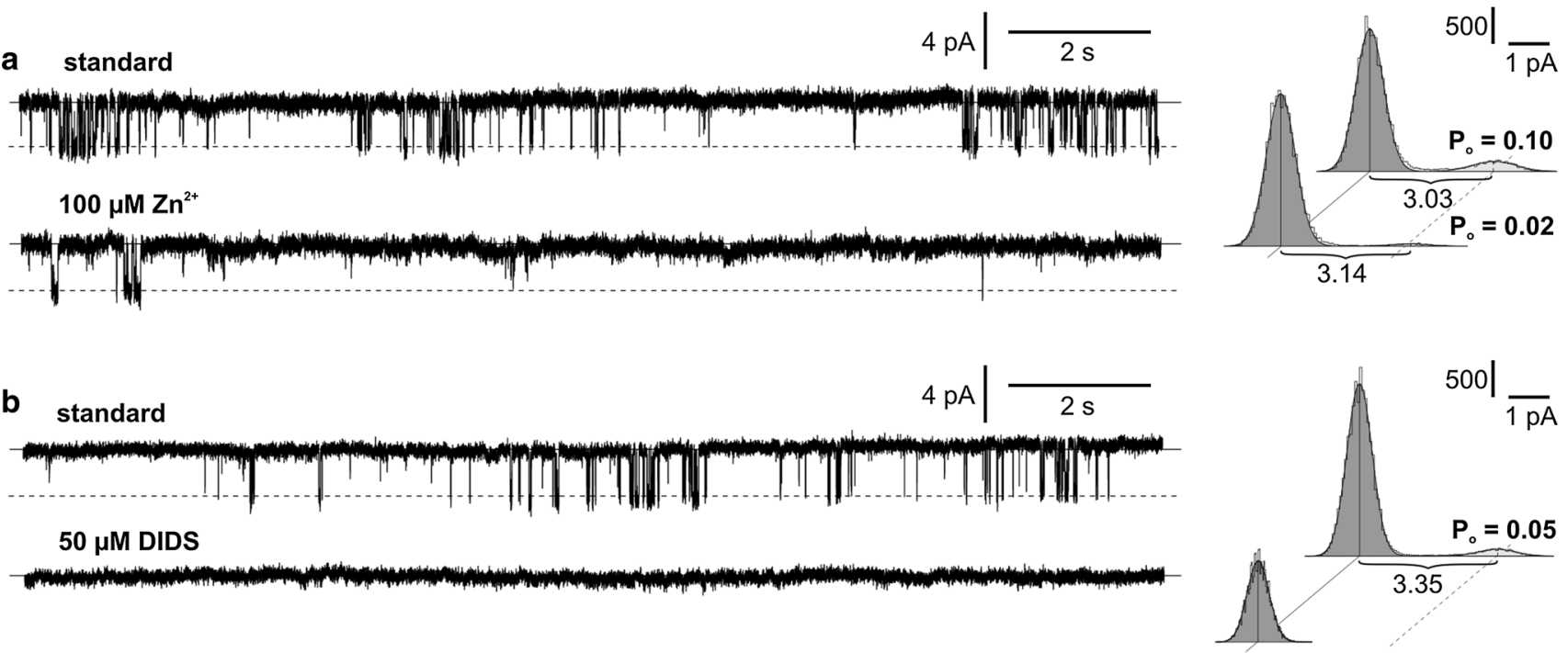

Fig. 5 Influence of chloride channel inhibitors, $\mathrm{ZnCl}_{2}$ (a) and DIDS (b) on the activity of chloride channels. The standard conditions were the same as in Fig. 2a. The cytoplasm-out recordings were obtained at the same patch at $-60 \mathrm{mV}$ 

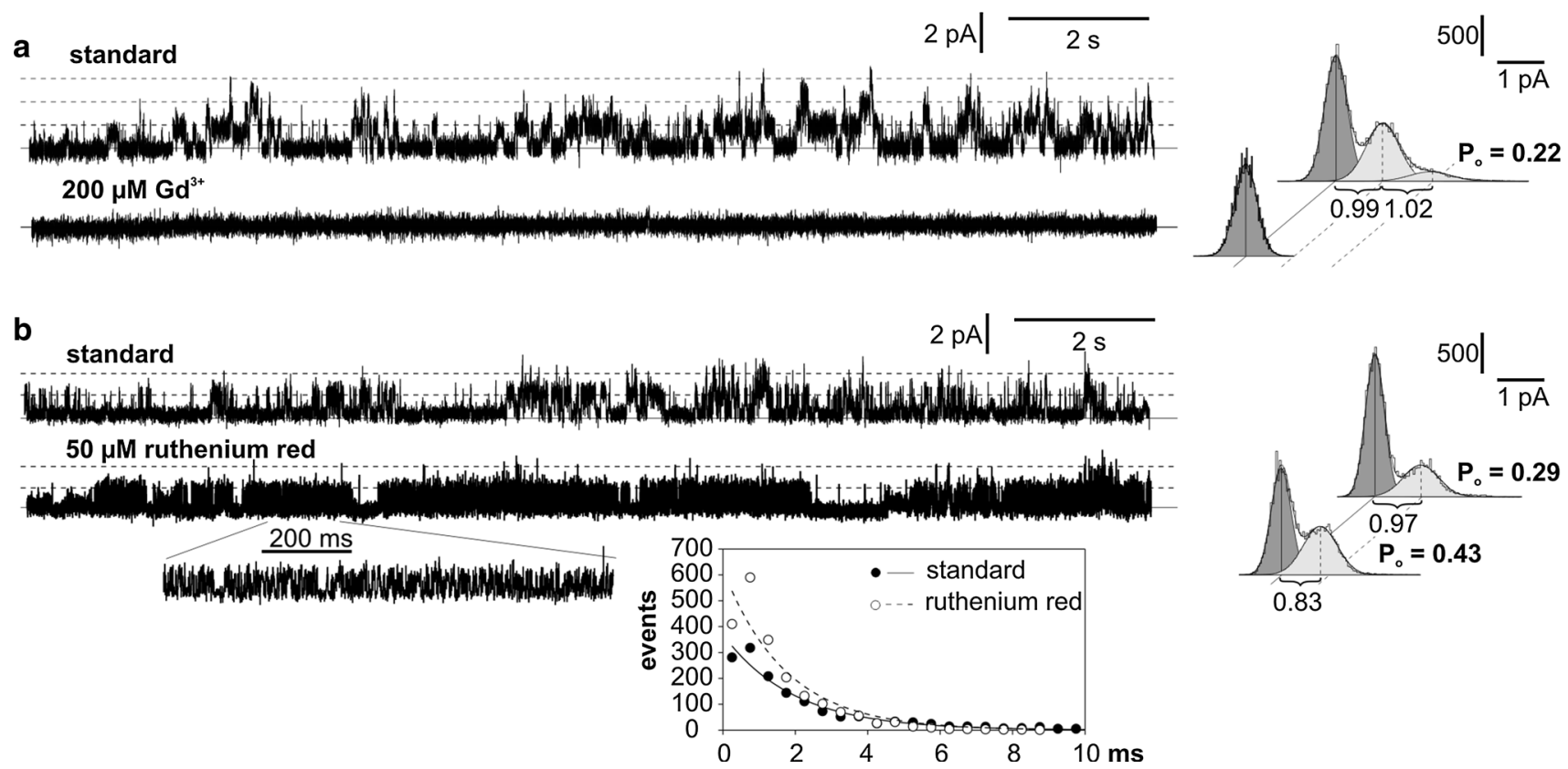

Fig. 6 Influence of calcium channel inhibitors, $\mathrm{GdCl}_{3}$ (a) and ruthenium red (b) on the activity of SV channels. The standard conditions were the same as in Fig. 2a. The cytoplasm-out recordings

(up to ca. $5 \mathrm{~ms}$ ) openings of the channels (see the inset in Fig. 6b). The next effect observed after ruthenium red was a decrease in the conductance of the channels from 24 to 21 $\mathrm{pS}$.

\section{Discussion}

The results presented in this work demonstrate that at least two channel types are active in the tonoplast of the liverwort $M$. polymorha-slow activated potassium-permeable channels and fast activated chloride-permeable channels. The slow activated channels found in Marchantia share many features with SV channels-the best known plant vacuolar channels found also in species related to Marchantia, i.e. C. conicum (Trębacz and Schönknecht 2000; Trębacz et al. 2007) and P. patens (Koselski et al. 2013). The same channels in A. thaliana are encoded by the AtTPC1 gene, since tpcl knockout mutants exhibit lack of SV channel activity (Peiter et al. 2005). In Marchantia, similar as in other plants, SV channels are outward rectifiers and allow potassium to pass from the cytoplasm to the vacuole. Moreover, the channels possess another feature that is characteristic for SV channels-dependence on cytoplasmic calcium (Fig. 3a). In comparison to potassium channels, classification of chloride channels is more difficult, because vacuolar anion channels in plant cells are not as well known as SV channels. Vacuolar anion channels were recorded previously in $C$. conicum (Trębacz et al. were obtained at the same patch at $+40 \mathrm{mV}$. The event detection analysis placed at the bottom of $\mathbf{b}$ was based on the presented traces

2007), but they were activated by a high cytoplasmic concentration of magnesium $(50 \mathrm{mM})$ and a low concentration of $\mathrm{Ca}^{2+}$ (not added to the cytoplasmic side). Anion channels from Conocephalum were permeable to many anions, including chloride, and carried the ions in the same direction as the channels in Marchantia. Both channels differed in conductance, which at $-100 \mathrm{mV}$ amounted to $32 \mathrm{pS}$ in Conocephalum and $49 \pm 1 \mathrm{pS}$ in our study (Fig. 2d). However, such differences could be an effect of different conditions used during the measurements. The anion channels in Conocephalum were recorded in an almost symmetrical concentration of $100 \mathrm{mM} \mathrm{Cl}^{-}$(cytoplasmic $100 \mathrm{mM} \mathrm{Cl}^{-}$and vacuolar $104 \mathrm{mM} \mathrm{Cl}^{-}$); in our study, an approximately tenfold lower concentration of $\mathrm{Cl}^{-}$ was used on the vacuolar side, facilitating $\mathrm{Cl}^{-}$fluxes toward the vacuole. Substantially higher conductance than in Marchantia was recorded in the anion-permeable vacuolar channels from Physcomitrella (108 pS obtained at $-80 \mathrm{mV}$ in symmetrical $208 \mathrm{mM} \mathrm{Cl}^{-}$) (Koselski et al. 2015). These channels were permeable to nitrate and chloride with a $\mathrm{NO}_{3}{ }^{-} / \mathrm{Cl}^{-}$permeability ratio of 3.08 and carried the anions in the same direction as the anion channels from Marchantia and Conocephalum. The channels from Physcomitrella, unlike in our study, were recorded after inhibition of SV channels. Such dependence of anion channels and SV channel activity was not observed in Marchantia, since both the channels were recorded simultaneously (Fig. 2a). The next difference between the anion channels recorded in Physcomitrella and 


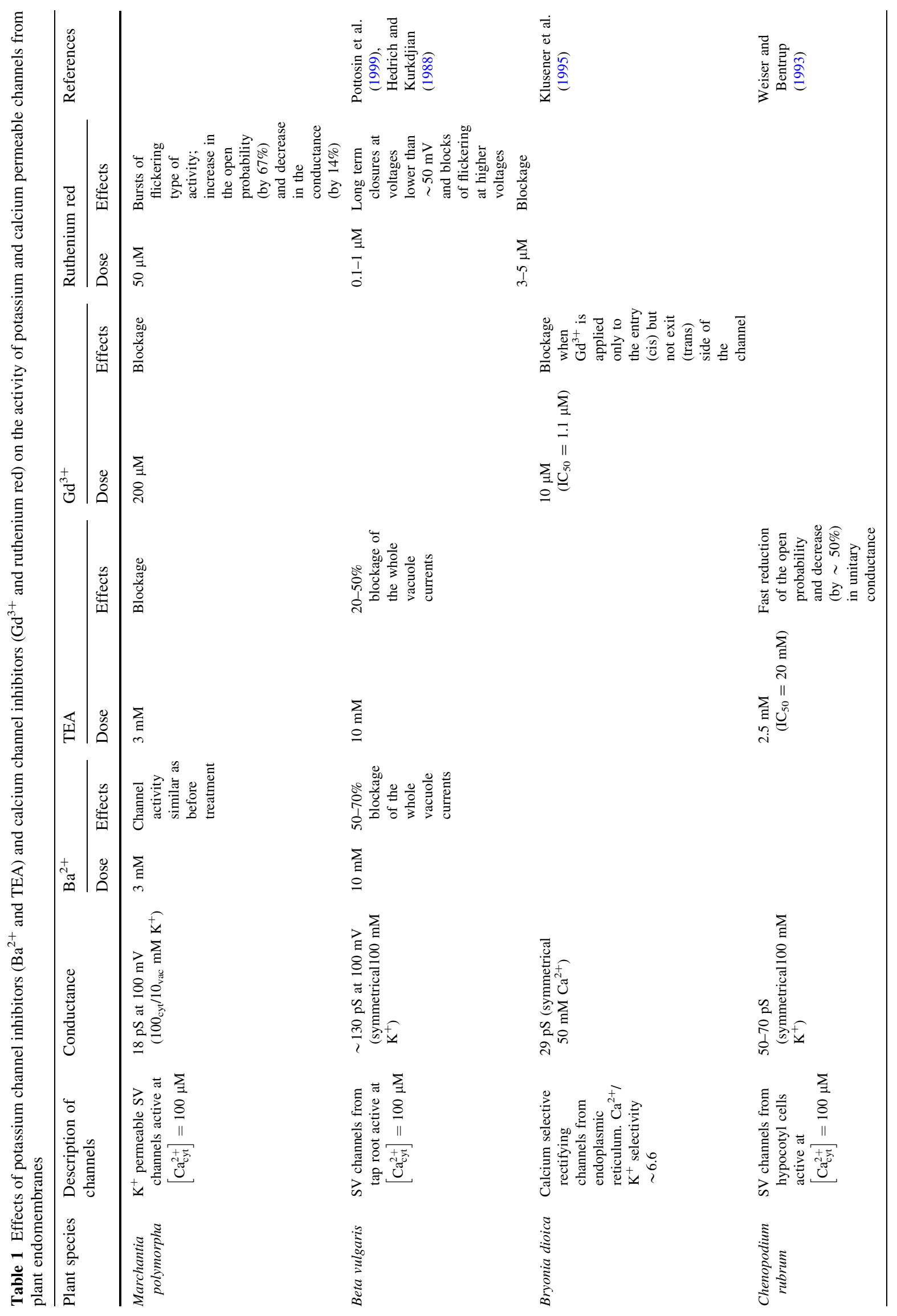




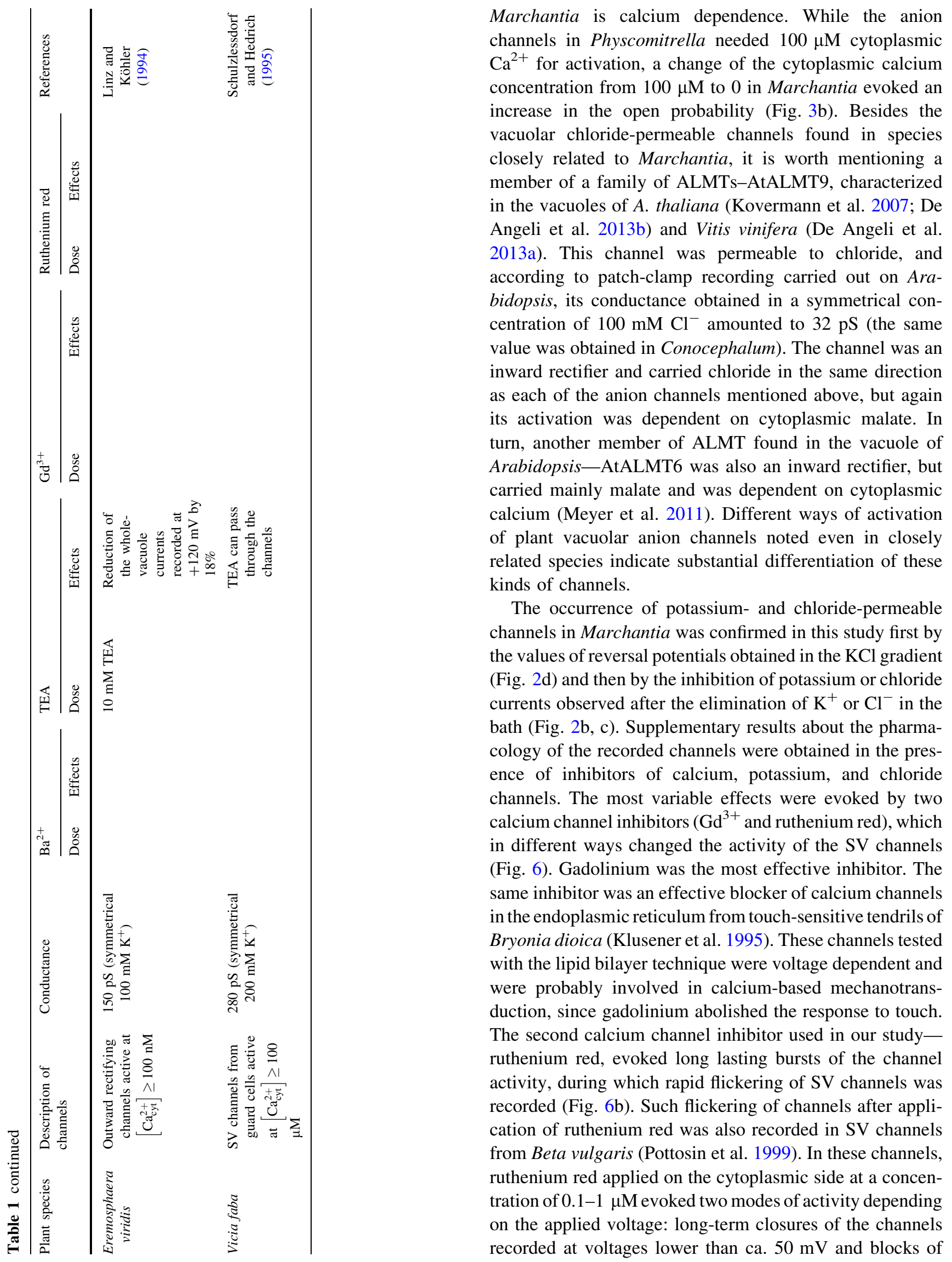


Table 2 Effects of anion channel inhibitors (DIDS and $\mathrm{Zn}^{2+}$ ) on the activity of anion permeable channels from plant vacuoles

\begin{tabular}{|c|c|c|c|c|c|c|c|}
\hline \multirow[t]{2}{*}{ Plant species } & \multirow{2}{*}{$\begin{array}{l}\text { Description of the } \\
\text { channels }\end{array}$} & \multirow[t]{2}{*}{ Conductance } & \multicolumn{2}{|l|}{ DIDS } & \multicolumn{2}{|l|}{$\mathrm{Zn}^{2+}$} & \multirow[t]{2}{*}{ References } \\
\hline & & & Dose & Effects & Dose & Effects & \\
\hline $\begin{array}{l}\text { Marchantia } \\
\text { polymorpha }\end{array}$ & $\begin{array}{l}\text { Permeable to chloride } \\
\text { inward rectifying } \\
\text { channels active at } \\
{\left[\mathrm{Ca}_{\text {cyt }}^{2+}\right] \geq 0 \mathrm{mM}}\end{array}$ & $\begin{array}{l}49 \mathrm{pS} \text { at } \\
-100 \mathrm{mV} \\
\left(104.2_{\mathrm{cyt}} / 14.2_{\mathrm{vac}}\right. \\
\left.\mathrm{mM} \mathrm{Cl}^{-}\right)\end{array}$ & $50 \mu \mathrm{M}$ & Blockage & $100 \mu \mathrm{M}$ & $\begin{array}{l}\text { Decrease in the open } \\
\text { probability } \\
\text { recorded a few } \\
\text { minutes after } \\
\text { application of the } \\
\text { inhibitor }\end{array}$ & \\
\hline $\begin{array}{l}\text { Conocephalum } \\
\text { conicum }\end{array}$ & $\begin{array}{l}\text { Anion permeable } \\
\text { channels activated by } \\
50 \mathrm{mM} \text { cytoplasmic } \\
\mathrm{Mg}^{2+} \text { and low } \\
\text { concentration of } \mathrm{Ca}^{2+} \\
\text { (not added) }\end{array}$ & $\begin{array}{l}32 \mathrm{pS} \text { at } \\
-100 \mathrm{mV} \\
\left(100_{\mathrm{cyt}} / 104_{\mathrm{vac}}\right. \\
\left.\mathrm{mM} \mathrm{Cl}^{-}\right)\end{array}$ & $1 \mathrm{mM}$ & $\begin{array}{l}\text { Decrease in } \\
\text { currents recorded } \\
\text { at }-100 \mathrm{mV} \text { in } \\
\text { cytoplasm-out } \\
\text { macropatches by } \\
\sim 61 \%\end{array}$ & & & $\begin{array}{l}\text { Trebacz } \\
\text { et al. } \\
(2007)\end{array}$ \\
\hline Beta vulgaris & $\begin{array}{l}\text { Time dependent channels } \\
\text { passing malate into the } \\
\text { vacuole. } \mathrm{Mal}^{2-} / \mathrm{K}^{+} \\
\text {selectivity was } 6 \div 10\end{array}$ & $\begin{array}{l}\approx 25 \mathrm{pS} \text { at } \\
-80 \mathrm{mV} \\
\left(100_{\text {cyt }} / 10_{\text {vac }}\right. \\
\left.\mathrm{mM} \mathrm{Mal}^{2-}\right)\end{array}$ & & & $2.5 \mathrm{mM}$ & $\begin{array}{l}\text { Blockage of the } \\
\text { whole vacuolar } \\
\text { currents }\end{array}$ & $\begin{array}{l}\text { Pantoja } \\
\text { et al. } \\
(1992 a)\end{array}$ \\
\hline
\end{tabular}

flickering of the channels recorded at more positive voltages. At a higher concentration of ruthenium red $(3-5 \mu \mathrm{M}), \mathrm{SV}$ channels from Beta vulgaris, in contrast to SV channels from Marchantia, were blocked. Apart from SV channels, the ryanodine receptor (RyR), which acts in the animal storage/ release organelles as a $\mathrm{Ca}^{2+}$ release channel (Fill and Copello 2002), is sensitive to ruthenium red (Xu et al. 1999). However, no RyR homolog has been found in land plants (Schönknecht 2013).

The SV channels in Marchantia were blocked by TEA (Fig. 4b), i.e. an inhibitor commonly used for blocking of many types of potassium channels. TEA blocks SV channels from higher plants e.g. Chenopodium rubrum (Weiser and Bentrup 1993) and Beta vulgaris (Hedrich and Kurkdjian 1988). Weak effectiveness of this inhibitor (reduction of whole-vacuolar SV currents by $18 \%$ after application of $10 \mathrm{mM}$ TEA) was recorded in the green alga Eremosphaera viridis (Linz and Köhler 1994). On the other hand, a patch-clamp study carried out by Schulzlessdorf and Hedrich (1995) proved TEA-permeability of SV channels from guard cells of Vicia faba. Interestingly, the SV channels from Marchantia were not blocked by another inhibitor of potassium channelsbarium, which at the $10 \mathrm{mM}$ concentration inhibited SV currents from Beta with higher efficiency (50-70\% of inhibition) than $10 \mathrm{mM}$ TEA (20-50\% of inhibition) (Hedrich and Kurkdjian 1988). On the other hand, a patch-clamp study carried out by Pantoja et al. (1992b) indicated that SV channels from Beta are permeable to barium. Apart from barium, there are many monovalent $\left(\mathrm{K}^{+}, \mathrm{Na}^{+}, \mathrm{Rb}^{+}, \mathrm{Cs}^{+}\right)$and divalent $\left(\mathrm{Ca}^{2+}, \mathrm{Mg}^{2+}\right)$ cations for which low selectivity of $\mathrm{SV}$ channels has been documented (White 2000). Probably, low selectivity to cations occurs also in the SV channels from Marchantia. This assumption is supported by the differences in $E_{\mathrm{K}}$ and $E_{\mathrm{rev}}$ obtained in the $\mathrm{K}^{+}$gradient (Fig. 2d), but in the presence of the symmetrical concentration of $\mathrm{Ca}^{2+}$, whose fluxes through SV channels were documented previously in $P$. patens (Koselski et al. 2013), Vicia faba (Schulzlessdorf and Hedrich 1995; Ward and Schroeder 1994), and Beta vulgaris (Pottosin et al. 2001). Low selectivity and permeability to mono- and divalent cations, if existing in the SV channels from Marchantia, can explain the lack of blockage of these channels by barium.

To date, there is insufficient knowledge about the influence of anion channel inhibitors on the activity of anion channels from the vacuole. Two of the known anion channel inhibitors, DIDS and $\mathrm{Zn}^{2+}$, were effective in blocking the activity of chloride-permeable channels in Marchantia (Fig. 5). The channel activity was also abolished by replacement of $\mathrm{Cl}^{-}$by gluconate, which is impermeable to chloride channels (Fig. 2c). The effectiveness of some anion channel inhibitors, including DIDS, was also confirmed in vacuolar anion channels from Conocephalum (Trębacz et al. 2007). Besides blocking the chloride channels from Marchantia, $\mathrm{Zn}^{2+}$ was also an effective blocker of malatepermeable vacuolar channels from Beta (Pantoja et al. 1992a), which was considered as the route for malate movement into the vacuole. Together with the above-mentioned results obtained in Conocephalum and Beta, our investigation is so far the only study that concerns the pharmacology of plant vacuolar anion channels.

Tables 1 and 2 were prepared to facilitate the comparison of the effects of calcium, potassium, and anion channel inhibitors in Marchantia and other plants described earlier. 
In conclusion, this study demonstrates for the first time simultaneous activity of potassium- and chloride-permeable channels in the vacuoles of $M$. polymorpha. The first type of channels resemble SV channels known from higher and lower plants, but classification of the other type of channels was more difficult. The activation of chloridepermeable channels was not dependent on the activating factors of vacuolar anion channels known from other plants, also closely related to Marchantia, e.g. the liverwort $C$. conicum and the moss $P$. patens. The pharmacological studies of the recorded channels proved high efficiency of the DIDS and $\mathrm{Zn}^{2+}$ inhibitors of anion channels in blocking chloride channels and different effects of calcium and potassium channel inhibitors in respect to SV channels.

Author contribution statement KM conceived and designed research, performed the experiments, analysed the collected data, and wrote the main part of the manuscript. TK reviewed the manuscript, participated in writing, and received a grant from the NCN (National Science Centre) no. 2013/09/B/NZ1/01052. DH reviewed the manuscript. All authors have read and approved the final version of the manuscript.

Acknowledgements This work was supported by NCN (National Science Centre) Grant No. 2013/09/B/NZ1/01052.

Open Access This article is distributed under the terms of the Creative Commons Attribution 4.0 International License (http://creative commons.org/licenses/by/4.0/), which permits unrestricted use, distribution, and reproduction in any medium, provided you give appropriate credit to the original author(s) and the source, provide a link to the Creative Commons license, and indicate if changes were made.

\section{References}

Allen GJ, Sanders D (1996) Control of ionic currents in guard cell vacuoles by cytosolic and luminal calcium. Plant $\mathrm{J}$ 10(6):1055-1069

Allen GJ, Muir SR, Sanders D (1995) Release of $\mathrm{Ca}^{2+}$ from individual plant vacuoles by both InsP3 and cyclic ADP-ribose. Science 268(5211):735-737. doi:10.1126/science.7732384

Allen GJ, Amtmann A, Sanders D (1998) Calcium-dependent and calcium-independent $\mathrm{K}^{+}$mobilization channels in Vicia faba guard cell vacuoles. J Exp Bot 49:305-318

Bertl A, Blumwald E, Coronado R, Eisenberg R, Findlay G, Gradmann D, Hille B, Kohler K, Kolb HA, Macrobbie E, Meissner G, Miller C, Neher E, Palade P, Pantoja O, Sanders D, Schroeder J, Slayman C, Spanswick R, Walker A, Williams A (1992) Electrical measurements on endomembranes. Science 258(5084):873-874

Bethke PC, Jones RL (1994) $\mathrm{Ca}^{2+}$-calmodulin modulates ion channel activity in storage protein vacuoles of barley aleurone cells. Plant Cell 6(2):277-285

Bethke PC, Jones RL (1997) Reversible protein phosphorylation regulates the activity of the slow-vacuolar ion channel. Plant $\mathrm{J}$ 11(6):1227-1235. doi:10.1046/j.1365-313X.1997.11061227.x
Choi WG, Toyota M, Kim SH, Hilleary R, Gilroy S (2014) Salt stressinduced $\mathrm{Ca}^{2+}$ waves are associated with rapid, long-distance root-to-shoot signaling in plants. P Natl Acad Sci USA 111(17):6497-6502. doi:10.1073/pnas.1319955111

De Angeli A, Baetz U, Francisco R, Zhang J, Chaves MM, Regalado A (2013a) The vacuolar channel VvALMT9 mediates malate and tartrate accumulation in berries of Vitis vinifera. Planta 238(2):283-291. doi:10.1007/s00425-013-1888-y

De Angeli A, Zhang J, Meyer S, Martinoia E (2013b) AtALMT9 is a malate-activated vacuolar chloride channel required for stomatal opening in Arabidopsis. Nat Commun 4. doi:10.1038/ncomms2815

Dziubinska H, Paszewski A, Trebacz K, Zawadzki T (1983) Electrical activity of the liverwort Conocephalum conicum: the all-ornothing law, strength-duration relation, refractory periods and intracellular potentials. Physiol Plant 57(2):279-284. doi:10. 1111/j.1399-3054.1983.tb00911.x

Emmerlich V, Linka N, Reinhold T, Hurth MA, Traub M, Martinoia E, Neuhaus HE (2003) The plant homolog to the human sodium/ dicarboxylic cotransporter is the vacuolar malate carrier. P Natl Acad Sci USA 100(19):11122-11126. doi:10.1073/pnas. 1832002100

Fill M, Copello JA (2002) Ryanodine receptor calcium release channels. Physiol Rev 82(4):893-922. doi:10.1152/physrev. 00013.2002

Guo JT, Zeng WZ, Chen QF, Lee C, Chen LP, Yang Y, Cang CL, Ren DJ, Jiang YX (2016) Structure of the voltage-gated two-pore channel TPC1 from Arabidopsis thaliana. Nature 531(7593):196. doi:10.1038/nature16446

Hafke JB, Hafke Y, Smith JAC, Lüttge U, Thiel G (2003) Vacuolar malate uptake is mediated by an anion-selective inward rectifier. Plant J 35(1):116-128. doi:10.1046/j.1365-313X.2003.01781.x

Hedrich R, Kurkdjian A (1988) Characterization of an anionpermeable channel from sugar-beet vacuoles: effect of inhibitors. EMBO J 7(12):3661-3666

Hedrich R, Marten I (2011) TPC1-SV channels gain shape. Mol Plant 4(3):428-441. doi:10.1093/mp/ssr017

Hurth MA, Suh SJ, Kretzschmar T, Geis T, Bregante M, Gambale F, Martinoia E, Neuhaus HE (2005) Impaired pH homeostasis in Arabidopsis lacking the vacuolar dicarboxylate transporter and analysis of carboxylic acid transport across the tonoplast. Plant Physiol 137(3):901-910. doi:10.1104/pp.104.058453

Isayenkov S, Isner JC, Maathuis FJM (2010) Vacuolar ion channels: roles in plant nutrition and signalling. FEBS Lett 584(10):1982-1988. doi:10.1016/j.febslet.2010.02.050

Jaslan D, Mueller TD, Becker D, Schultz J, Cuin TA, Marten I, Dreyer I, Schönknecht G, Hedrich R (2016) Gating of the twopore cation channel AtTPC1 in the plant vacuole is based on a single voltage-sensing domain. Plant Biol 18(5):750-760. doi: $10.1111 / \mathrm{plb} .12478$

Kiep V, Vadassery J, Lattke J, Maass JP, Boland W, Peiter E, Mithöfer A (2015) Systemic cytosolic $\mathrm{Ca}^{2+}$ elevation is activated upon wounding and herbivory in Arabidopsis. New Phytol 207(4):996-1004. doi:10.1111/nph.13493

Klusener B, Boheim G, Liss H, Engelberth J, Weiler EW (1995) Gadolinium-sensitive, voltage-dependent calcium-release channels in the endoplasmic-reticulum of a higher-plant mechanoreceptor organ. EMBO J 14(12):2708-2714

Koselski M, Trebacz K, Dziubinska H (2013) Cation-permeable vacuolar ion channels in the moss Physcomitrella patens: a patch-clamp study. Planta 238(2):357-367. doi:10.1007/s00425013-1902-4

Koselski M, Dziubinska H, Seta-Koselska A, Trebacz K (2015) A nitrate-permeable ion channel in the tonoplast of the moss Physcomitrella patens. Planta 241(5):1207-1219. doi:10.1007/ s00425-015-2250-3 
Kovermann P, Meyer S, Hoertensteiner S, Picco C, Scholz-Starke J, Ravera S, Lee Y, Martinoia E (2007) The Arabidopsis vacuolar malate channel is a member of the ALMT family. Plant $\mathbf{J}$ 52(6):1169-1180. doi:10.1111/j.1365-313X.2007.03367.x

Krol E, Dziubinska H, Trebacz K (2003) Low-temperature induced transmembrane potential changes in the liverwort Conocephalum conicum. Plant Cell Physiol 44(5):527-533. doi:10.1093/pcp/ $\operatorname{pcg} 070$

Kupisz K, Trebacz K, Gruszecki WI (2015) Menthol-induced action potentials in Conocephalum conicum as a result of unspecific interactions between menthol and the lipid phase of the plasma membrane. Physiol Plant 154(3):349-357. doi:10.1111/ppl. 12288

Linz KW, Köhler K (1994) Vacuolar ion currents in the primitive green alga Eremosphera viridis: the electrical properties are suggestive of both the Characeae and higher plants. Protoplasma 179(1-2):34-45

Lv Q-D, Tang R-J, Liu H, Gao X-S, Li Y-Z, Zheng H-Q, Zhang H-X (2009) Cloning and molecular analyses of the Arabidopsis thaliana chloride channel gene family. Plant Sci 176(5):650-661. doi:10.1016/j.plantsci.2009.02.006

Meyer S, Scholz-Starke J, De Angeli A, Kovermann P, Burla B, Gambale F, Martinoia E (2011) Malate transport by the vacuolar AtALMT6 channel in guard cells is subject to multiple regulation. Plant J 67(2):247-257. doi:10.1111/j.1365-313X. 2011.04587.x

Pantoja O, Smith JAC (2002) Sensitivity of the plant vacuolar malate channel to $\mathrm{pH}, \mathrm{Ca}^{2+}$ and anion-channel blockers. J Membr Biol 186(1):31-42. doi:10.1007/s00232-001-0132-z

Pantoja O, Gelli A, Blumwald E (1992a) Characterization of vacuolar malate and $\mathrm{K}^{+}$channels under physiological conditions. Plant Physiol 100(3):1137-1141. doi:10.1104/pp.100.3.1137

Pantoja O, Gelli A, Blumwald E (1992b) Voltage-dependent calcium channels in plant vacuoles. Science 255(5051):1567-1570. doi:10.1126/science.255.5051.1567

Pei ZM, Ward JM, Harper JF, Schroeder JI (1996) A novel chloride channel in Vicia faba guard cell vacuoles activated by the serine/ threonine kinase, CDPK. EMBO J 15(23):6564-6574

Peiter E, Maathuis FJM, Mills LN, Knight H, Pelloux J, Hetherington AM, Sanders D (2005) The vacuolar $\mathrm{Ca}^{2+}$-activated channel TPC1 regulates germination and stomatal movement. Nature 434(7031):404-408. doi:10.1038/nature03381

Pottosin II, Schönknecht G (2007) Vacuolar calcium channels. J Exp Bot 58(7):1559-1569. doi:10.1093/jxb/erm035

Pottosin II, Dobrovinskaya OR, Muniz J (1999) Cooperative block of the plant endomembrane ion channel by ruthenium red. Biophys J 77(4):1973-1979

Pottosin II, Dobrovinskaya OR, Muniz J (2001) Conduction of monovalent and divalent cations in the slow vacuolar channel. J Membr Biol 181(1):55-65
Pottosin II, Martinez-Estevez M, Dobrovinskaya OR, Muniz J (2003) Potassium-selective channel in the red beet vacuolar membrane. J Exp Bot 54(383):663-667. doi:10.1093/jxb/erg067

Schönknecht G (2013) Calcium signals from the vacuole 2(4):589-614. doi:10.3390/plants2040589

Schulze C, Sticht H, Meyerhoff P, Dietrich P (2011) Differential contribution of EF-hands to the $\mathrm{Ca}^{2+}$-dependent activation in the plant two-pore channel TPC1. Plant J 68(3):424-432. doi:10. 1111/j.1365-313X.2011.04697.X

Schulzlessdorf B, Hedrich R (1995) Protons and calcium modulate SV-type channels in the vacuolar-lysosomal compartmentchannel interaction with calmodulin inhibitors. Planta 197(4):655-671

Tikhonova LI, Pottosin II, Dietz KJ, Schönknecht G (1997) Fastactivating cation channel in barley mesophyll vacuoles. Inhibition by calcium. Plant J 11(5). doi:10.1046/j.1365-313X.1997. 11051059.x

Trębacz K, Schönknecht G (2000) Simple method to isolate vacuoles and protoplasts for patch-clamp experiments. Protoplasma 213(1-2):39-45

Trebacz K, Zawadzki T (1985) Light-triggered action potentials in the liverwort Conocephalum conicum. Physiol Plant 64(4):482-486. doi:10.1111/j.1399-3054.1985.tb08526.x

Trębacz K, Schönknecht G, Dziubińska H, Hanaka A (2007) Characteristics of anion channels in the tonoplast of the liverwort Conocephalum conicum. Plant Cell Physiol 48(12):1747-1757. doi:10.1093/pcp/pcm 147

van den Wijngaard PWJ, Bunney TD, Roobeek I, Schönknecht G, de Boer AH (2001) Slow vacuolar channels from barley mesophyll cells are regulated by 14-3-3 proteins. FEBS Lett 488(1-2):100-104. doi:10.1016/s0014-5793(00)02394-2

von der Fecht-Bartenbach J, Bogner M, Dynowski M, Ludewig U (2010) CLC-b-mediated $\mathrm{NO}_{3}{ }^{-} / \mathrm{H}^{+}$exchange across the tonoplast of Arabidopsis vacuoles. Plant Cell Physiol 51(6):960-968. doi:10.1093/pcp/pcq062

Ward JM, Schroeder JI (1994) Calcium-activated $\mathrm{K}^{+}$channels and calcium-induced calcium-release by slow vacuolar ion channels in guard-cell vacuoles implicated in the control of stomatal closure. Plant Cell 6(5):669-683. doi:10.2307/3869871

Weiser T, Bentrup FW (1993) Pharmacology of the SV channels in the vacuolar membrane of Chenopodium rubrum suspension cells. J Membr Biol 136(1):43-54

White PJ (2000) Calcium channels in higher plants. BBA Biomembr 1465(1-2):171-189. doi:10.1016/s0005-2736(00)00137-1

Xu L, Tripathy A, Pasek DA, Meissner G (1999) Ruthenium red modifies the cardiac and skeletal muscle $\mathrm{Ca}^{2+}$ release channels (ryanodine receptors) by multiple mechanisms. J Biol Chem 274(46):32680-32691. doi:10.1074/jbc.274.46.32680 